\title{
Understanding the Linkage between University Students' and Instructors Use of Online Resources and Their Academic Attainment in Social Studies
}

\author{
Thomas Ajayi ${ }^{1}$, Peter A. Amosun ${ }^{1}$, Olugbenga A. Ige ${ }^{2, *}$ \\ ${ }^{1}$ University of Ibadan, Ibadan, Nigeria \\ ${ }^{2}$ University of the Free State, Republic of South Africa
}

Received July 26, 2020; Revised April 8, 2021; Accepted May 16, 2021

\section{Cite This Paper in the following Citation Styles}

(a): [1] Thomas Ajayi, Peter A. Amosun, Olugbenga A. Ige, "Understanding the Linkage between University Students' and Instructors Use of Online Resources and Their Academic Attainment in Social Studies," Universal Journal of Educational Research, Vol. 9, No. 9, pp. 1611 - 1616, 2021. DOI: 10.13189/ujer.2021.090901.

(b): Thomas Ajayi, Peter A. Amosun, Olugbenga A. Ige (2021). Understanding the Linkage between University Students' and Instructors Use of Online Resources and Their Academic Attainment in Social Studies. Universal Journal of Educational Research, 9(9), 1611 - 1616. DOI: 10.13189/ujer.2021.090901.

Copyright $(2021$ by authors, all rights reserved. Authors agree that this article remains permanently open access under the terms of the Creative Commons Attribution License 4.0 International License

\begin{abstract}
Few decades ago, the Internet became a new home for academic research and a spot where teaching and learning materials could be found. A cursory look at previous studies on university instructors' use of online resources shows intermittent influence students' academic outcomes in Nigerian schools. Although, several efforts have been put in place to establish a cordial and steady relationship between university instructors' use of online resources and the students' academic attainment in Nigerian schools, it seems that there is paucity of studies on the linkage between university instructors' use of online resources and students' academic attainment in Social Studies. This research explored the relationship between Social Studies lecturers' use of online resources and students' performance in the course. This study adopted descriptive research using correlational design, and purposive sampling technique. 398 students at two Bachelor of Education degree-awarding institutions in Nigeria responded to the questionnaire. The data collected were analyzed using frequency counts, percentage, mean and standard deviation and Pearson Product Moment Correlation. The outcomes of this discourse indicated no significant relationship between Social Studies lecturers' use of online resources and students' performance in the course. Additionally, it was evident from the results that the extent to which Social Studies students' use of online resources in the selected tertiary institutions in Nigeria was
\end{abstract}

high. This paper, therefore, concludes that the use of online resources has no significant relationship with students' performance in Social Studies. It was recommended that university instructors should grasp a new means in the use of online resources in the classroom in order to foster a good lecturer-students interaction that would eventually results in great academic attainment of students in the course.

Keywords University Instructors, Students' Academic Attainment, Social Studies, Online Resources

\section{Introduction}

Contemporary Social Studies instructors are required to use modern teaching resources such as electronic materials to make teaching effective, understandable, and comprehensive to learners. When learners are taught in a unique way, there is always a higher degree of comprehension and appreciation of the subject-matter learned and greater would be the attainment of the stated objectives. After all, the adequate use of online resources can be made to achieve this purpose. It is worth saying that there is no perfect education system anywhere in the world. Every field of knowledge has its own imperfection, and 
Social Studies is no exception. It was observed that university instructors' use of online resources has shown intermittent influence on students' academic outcomes in Social Studies in the past few years.

Social Studies has been defined by several authorities based on their own perceptions of the subject. For instance, Kissling [8] stated that The National Council for the Social Studies $[11,12]$ described social studies as "the integrated study of the social sciences and humanities to promote civic competence" (p.9). In a similar vein, Edinyang and Efiom [4] described Social Studies as an integrated discipline that examines man in his environment in order to sensitize man with his symbolic environmental relationships and equip him with the life skills that are necessary to identify and conquer his environmental problems. These definitions attest to the importance of man's immediate environment and holistically study his activities.

Technology in the $21^{\text {st }}$ century is becoming an essential tool in the teaching and learning of the social science disciplines. Teachers, researchers, students as well as other users can access easier and faster information in different places, for instance, on the Internet for learning materials to enhance lectures, boost research, and for other academic-related purposes. The learners on the other hand can use technological product such as electronic resources to expand their knowledge on concepts taught by their teachers in the classroom by searching for other exceptional points in the course of browsing the Internet, which were not mentioned at the time of their interaction. Scholars posited that these learning resources that were accessible online included e-journals, e-books, online databases, e-magazines, e-newspapers [10] electronic conference proceedings, e-encyclopedia, CD-ROM databases, Online Public Access Catalogue $\{$ OPAC (Kaur \& Walia [7]; Akande-Alasoka, 2018). Apuke and Iyendo [2] opined that these technological resources have reconstructed the tertiary educational practices by improving academic learning and students' learning outcomes.

This research suggests that students' use of online resources and their level of academic attainment are strongly influenced by their teachers' level of knowledge of online resources availability as well as the teachers' use of the online learning resources. In Nigerian educational system today, it is expected of the teachers especially at the tertiary level to incorporate technology into teaching. Thus, this is an expectation on the part of the university lecturers to integrate teaching technology into their daily activities. This is because, the decision about whether to use online resources in the classroom to enhance teaching is always made by instructors.

Sadiat [15] in Posigha, Oghuvwu, and Sunday [14] evaluated undergraduates' use of e-books and reported that most undergraduates at the selected universities were not only aware of electronic books but preferred them to printed books. In a similar study on the use of online resources, Kumar and Manjunath [9] in Senthil [17] investigated the Internet sources and services highly used by teachers and researchers in the university setup, and discovered that most of the selected teachers and researchers supported their instructional delivery with the Internet. It was discovered that Internet use had impact on the teachers' academic performance. University instructors' use of online resources has shown intermittent influence on students' academic outcomes in the Nigerian schools despite several efforts which have been put in place to establish a cordial and steady relationship between university instructors' use of online resources and university students' learning outcomes. It seems that there is a dearth of studies on the linkage between university instructors' use of online resources and undergraduates' academic attainment in Social Studies. It is in the light of this that this study explored the relationship between university instructors' use of online resources and undergraduates' academic attainment in Social Studies in two selected tertiary institutions of higher learning in Nigeria.

\section{University Students' Use of Online Resources}

Higher education students to meet diverse academic needs use online academic resources. Tylor [18] affirmed that the world wide web has become substantial in the process of gathering information. It was evident from this assertion that the world wide web makes available billion of academic resources to university students. These online resources are not specific to educational use solely, but to other aspects of human activities [18]. For instance, Beaudion and Tao [19] modelled the impact of online cancer resources on a sample of people supporting cancer patients. Beaudion and Tao [19] indicated and analysed ten potential paths of mediation among synchronous, asynchronous, social interaction, social support, stress and depression. In this research conducted by Beaudion and Tao [19], a three-stepped structural equation model was initially adopted to evaluate the influence of Internet use on social capital and its further effect on health outcomes. Beaudion and Tao [19] then modified this model to evaluate if the other paths added after the non-significant paths were pruned improved the three-stepped structural equation model that suggested mediation. The outcomes of the research reported by Beaudion and Tao [19] affirmed that social interaction and social support mediated asynchronous communications (online and offline) powered by online communication mediated the impact on stress and depression.

The research reported by Dukić \& Strišković [20] took a similar internet-based design adopted by Beaudion and Tao [19]. Dukić \& Strišković [20] evaluated the use and perception of electronic resources by Croatian university students. This research explored the latent factors that influenced the perceptions of university students on 
electronic resources and analyzed variations in the sociodemographic characteristics of the students using Google Docs online questionnaire. The data provided by 900 university students in Croatia that were analysed using descriptive statistics, Mann-Whitney and Kruskal-Wallis tests to evaluate the significance of the frequency at which the selected students used Internet resources in relation to variables such as gender, level of study, enrollment status, and subject specialisations. The results reported by Dukić \& Strišković [20] affirm that encyclopaedias and dictionaries such as Wikipedia were most acceptable sources of information and support in learning. The changes brought about by the escalation of Covid-19 pandemic would have changed the situation reported by Dukić \& Strišković (2015) since other sources of information that support teaching and learning would have evolved in Eastern Europe. Other popular sources of information that the selected 900 Croatian university students have used to support their teaching-learning activities were university websites, e-journals, e-books, personal websites, blogs, and discussion forums. The intersection of the popular sources of information identified by [20] and this current study is that the acceptability of these popular sources identified by Croatian university students were evaluated among the university students selected for this study in Nigeria. It is in the light of the foregoing that this study answered this question "How often do Social Studies students use online resources in Ondo State tertiary institutions?" and test this hypothesis "There is no significant relationship between Social Studies lecturers' online resources usage and undergraduates' performance in social studies."

\section{Methodology}

This study is a descriptive research using correlational design. The study population was made up of all 300 and 400 Level Social Studies undergraduate students from two selected universities in Nigeria. The sample of this study was made up of 398 B.Ed Social Studies undergraduates students from the two selected institutions. The schools were purposively selected based on the criteria that they were government owned institutions where Social Studies is offered as a course of study. In each school, a total of 200 students comprising 300 and 400 level students were projected for selection. This was because the 300 and 400 level students have stayed over two years on the programme and they would have been able to take decision regarding the use of online resources by themselves and their lecturers, as well as their performance in the course. Meanwhile, it was only 198 students that completed and returned the questionnaire at the first institution selected while 200 students completed the questionnaire at the second institution. This, therefore, made the total of the sample to be 398 Social Studies students.

Social Studies Students' Use of Online Resources Questionnaire (SSSUORQ) was a self-designed instrument by the researcher to collect data from the students in assessing their uses of online resources. The items evaluated the students' responses on the use of online resources. The instrument used was validated using both face and content validity. The instrument's reliability was carried out with Cronbach Alpha test of reliability coefficients which gave 0.81 .

The other instrument was a "B.Ed Social Studies Achievement Test (B.Ed SSAT)" designed by the researcher to evaluate the students' achievement in Social Studies. The instrument was subjected to Kuder-Richardson 20 reliability coefficients which gave 0.70. The data collected were analyzed using both descriptive and inferential statistics. The data collected in this research were subjected to frequency counts, percentages, mean, standard deviation, and Pearson Product Moment Correlation (e.g., Banmeke \& Omoregbe, [3]).

\section{Presentation of Results}

\section{Answers to Research Questions}

Research Question 1: How often do Social Studies students use online resources in the selected tertiary institutions?

Table 1 shows the extent to which Social Studies students use online resources. The table shows that the following online resources were often used by the students: E-journal $(\bar{x}=2.85)$, E-documents $(\bar{x}=2.81)$, E-books $(\bar{x}=3.01)$, Online encyclopedia services $(\bar{x}=3.12)$, E-databases $(\bar{x}=2.99)$, Digital library $(\bar{x}=2.90)$, Online Public Access Catalogue (OPAC) $(\bar{x}=2.78)$, Electronic References $(\bar{x}=2.94)$, Online discussion group ( $\bar{x}=3.21)$, E-dictionary $(\bar{x}=3.09)$, E-preprints and E-prints $(\bar{x}=2.78)$, Software $(\bar{x}=3.03)$, E-theses and dissertations $(\bar{x}=2.52)$, E-magazines $(\bar{x}=2.96)$, E-newspapers $(\bar{x}=3.04)$, E-bulletin board services $(\bar{x}=$ 2.77), E-reports $(\bar{x}=2.72)$, CD-ROM $(\bar{x}=2.70)$ and E-contents $(\bar{x}=2.64)$. Furthermore, the table shows that E-clippings $(\bar{x}=2.70)$ are seldom used by the students. Meanwhile based on the value of the weighted average (2.86 out of 4.00 maximum value obtainable) which falls within the decision value for high, it can be inferred that the extent to which Social Studies students use online resources in the selected tertiary institutions was high. 
Table 1. Online Resources Usage by Social Studies Students

\begin{tabular}{|c|c|c|c|c|c|c|c|}
\hline $\mathbf{S} / \mathbf{N}$ & Item & Very Often & Often & Sometimes & Never & Mean & Std. D. \\
\hline 1 & E-journal & $117(29.4)$ & $163(41)$ & $60(15.1)$ & $58(14.6)$ & 2.85 & 1.00 \\
\hline 2 & E-documents & $94(23.6)$ & $185(46.5)$ & $71(17.8)$ & $48(12.1)$ & 2.81 & .93 \\
\hline 3 & E-books & $125(31.4)$ & $179(45)$ & $67(16.8)$ & $27(6.8)$ & 3.01 & .86 \\
\hline 4 & Online encyclopedia services & $165(41.5)$ & $144(36.2)$ & $63(15.8)$ & $26(6.5)$ & 3.12 & .90 \\
\hline 5 & E-databases & $153(38.4)$ & $135(33.9)$ & $66(16.6)$ & $44(11.1)$ & 2.99 & .99 \\
\hline 6 & Digital Library & $147(36.9)$ & $115(28.9)$ & $87(21.9)$ & $49(12.3)$ & 2.90 & 1.03 \\
\hline 7 & $\begin{array}{l}\text { Online Public Access Catalogue } \\
\text { (OPAC) }\end{array}$ & $109(27.4)$ & $149(37.4)$ & $84(21.1)$ & $56(14.1)$ & 2.78 & 1.00 \\
\hline 8 & Electronic References & $148(37.2)$ & $136(34.2)$ & $58(14.6)$ & $56(14.1)$ & 2.94 & 1.03 \\
\hline 9 & Online discussion group & $187(47)$ & $137(34.4)$ & $45(11.3)$ & $29(7.3)$ & 3.21 & .91 \\
\hline 10 & E-dictionary & $173(43.5)$ & $136(34.2)$ & $44(11.1)$ & $45(11.3)$ & 3.09 & .99 \\
\hline 11 & E-preprints and E-prints & $101(25.4)$ & $157(39.4)$ & $95(23.9)$ & $45(11.3)$ & 2.78 & .94 \\
\hline 12 & Software & $148(37.2)$ & $146(36.7)$ & $74(18.6)$ & $30(7.5)$ & 3.03 & .92 \\
\hline 13 & E-theses and dissertations & $93(23.4)$ & $114(28.6)$ & $99(24.9)$ & $92(23.1)$ & 2.52 & 1.08 \\
\hline 14 & E-magazines & $140(35.2)$ & $151(37.9)$ & $61(15.3)$ & $46(11.6)$ & 2.96 & .98 \\
\hline 15 & E-newspapers & $149(37.4)$ & $164(41.2)$ & $40(10.1)$ & $45(11.3)$ & 3.04 & .96 \\
\hline 16 & E-bulletin board services & $122(30.7)$ & $143(35.9)$ & $54(13.6)$ & $79(19.8)$ & 2.77 & 1.08 \\
\hline 17 & E-reports & $112(28.1)$ & $140(35.2)$ & $72(18.1)$ & $74(18.6)$ & 2.72 & 1.06 \\
\hline 18 & E-clippings & $85(21.4)$ & $114(28.6)$ & $79(19.8)$ & $120(30.2)$ & 2.41 & 1.12 \\
\hline 19 & CD-ROM & $113(28.4)$ & $129(32.4)$ & $83(20.9)$ & $73(18.3)$ & 2.70 & 1.06 \\
\hline 20 & E-content pages & $108(27.1)$ & $120(30.2)$ & $92(23.1)$ & $78(19.6)$ & 2.64 & 1.07 \\
\hline \multicolumn{6}{|c|}{ Weighted Average } & \multicolumn{2}{|c|}{2.86} \\
\hline \multicolumn{8}{|c|}{$N=398$} \\
\hline \multicolumn{8}{|c|}{ Decision Value: $0.00-2.34=$ Low, $2.35-4.00=H i g h$} \\
\hline \multicolumn{8}{|c|}{$\begin{array}{l}\text { Note on Decision Value: Mean values of all the items in the table were added and divided by the number of items in the table. This gave the } \\
\text { mean weighted average of which } 4.00 \text { is the highest value that can be obtained. Any value of the weighted average that is between } 0.00 \text { and } \\
2.34 \text { was taken to stand for Low while the one between } 2.35 \text { and } 4.00 \text { was taken to stand High. }\end{array}$} \\
\hline
\end{tabular}

Table 2. Pearson Product Moment Correlation showing Relationship between Social Studies Lecturers' Use of Online Resources and Students' Performance in the Course

\begin{tabular}{|c|c|c|c|c|c|c|}
\hline Variable & Mean & Std. Deviation & N & R & Sig & Remark \\
\hline $\begin{array}{c}\text { Lecturers' Use of Online } \\
\text { Resources }\end{array}$ & 58.5 & 12.3 & & & & Not Significant \\
\hline $\begin{array}{c}\text { Students' Performance in Social } \\
\text { Studies }\end{array}$ & 36.5 & 13.8 & 398 & -.044 & .386 & \\
\hline
\end{tabular}

Ho1: There is no significant relationship between social studies lecturers' online resources usage and undergraduates' performance in Social Studies.

Table 2 shows that no significant relationship exists between Social Studies lecturers' use of online resources and students' performance in the course $(\mathrm{N}=398 ; \mathrm{r}=-.044$; $\mathrm{p}>0.05)$. Hence, hypothesis 3 was not rejected.

\section{Discussion of Findings}

Findings from this study report no relationship that is significant in Social Studies lecturers' online resources use and undergraduates' performance in this academic programme. This finding could be due to the fact that the online resources used by the Social Studies lecturers are not the type that can positively affect performance in Social Studies. Also, the findings could be as a result of the fact that the lecturers do not often make use of the online resources available to them. This could also be linked to the method used in the course of teaching. Another probable reason for the non-significant relationship between lecturers' use of online resources and undergraduates' performance in Social Studies could have emanated from 
unavailability of relevant learning materials which might have hindered their students' performance in the course. This finding is in consonance with Rozalind (2004) whose finding reveals that teachers and students use of technology had no significant effect on their grades and/or attendance. This finding also negates the finding of Kumar and Manjunath [9] whose finding revealed that there is a significance relationship between Internet use and teachers and researchers' academic performance. This finding also aligns with the far-sightedness of Ige and Hlalele [6] that called for unwavering commitment from stakeholders in Nigeria to adopt computer-aided strategies and discourage the reliance on teacher-centred method (modified conventional method).

Results from this study indicate that the extent to which Social Studies students use online resources in Ondo State tertiary institutions is high. This finding may be as a result of the fact that a large number of the students are aware of, and often make use of online resources. Consequent upon this, the extents to which they make use of, or utilize the online resources turn out to be high. This could also be attributed to the fact that different online resources are available to the students for use. This finding is in agreement with the finding of Emeka and Nyeche [5], whose finding showed that many students habitually used the Internet. This finding also corroborates the finding from previous research that undergraduates used the Internet for academic related development in Nigerian universities [13]. Also, this finding is in compliance with the finding of Ankrah, and Atuase [1] in Ternenge and Kashimana [16] whose finding revealed that the postgraduate students that participated in their study knew about the existence of e-resources in their university's library.

\section{Conclusion and Recommendation}

From this study, it has been established that the use of online resources does not have a significant effect on students' academic attainment in Social Studies especially at the selected tertiary institutions in Nigeria. Nevertheless, it could be concluded from these findings that no significant relationship was found in Social Studies lecturers' use of online resources and students' academic attainment in the course. Moreover, the extent to which Social Studies students used online resources in the selected tertiary institutions in Nigeria was high. It was recommended among other things that university instructors should devise new means in the use of online resources in the classroom in order to foster a good lecturer-students interaction that would eventually result into great academic attainment of students in the course.

\section{REFERENCES}

[1] Ankrah, E., and Atuase, D. 2018 "The Use of Electronic Resources Postgraduate students of the University of Cape Coast".Library. Philosophy and Practice (e-journal). 1632.

[2] Apuke, O. D. and Iyendo, T. O. 2018. University students' usage of the internet resources for research and learning: forms of access and perceptions of utility. Heliyon, 4 (2018) e01052. https://doi.org/10.1016/j.heliyon.2018.e01052.

[3] Banmeke, T.O.A. \& Omoregbe, F.E. (2009). Farmers' Perception of the Factors Militating against Rubber Production in Edo and Delta States of Nigeria. International Journal of Agricultural Economics \& Rural Development, 2(2), 33-39.

[4] Edinyang, S. D. and Effiom, N. V. 2017. Social Studies Teaching Resources in the $21^{\text {st }}$ Century. International Journal of Sociology and Anthropology Research, 3(4), 8-14.

[5] Emeka, U.J. and Nyeche, O.S. 2016, Impact of Internet Usage on the Academic Performance of Undergraduates Students: A case study of the University of Abuja, Nigeria. International Journal of Scientific \& Engineering Research. 7(10), Pp.1018-1029. Retrieved November 26, 2017, from https://www.ijser.org/researchpaper/Impact-of-Internet-Usa ge-on-the-Academic-Performance-of-Undergraduates-Stude nts--A-case-study-of-the-University-of-Abuja--Nigeria.pdf.

[6] Ige, O.A. and Hlalele, D.J. 2017. Effects of computer-aided and blended teaching strategies on students' achievement in civic education concepts in mountain learning ecologies. Education and Information Technologies, 22, 2693-2709.

[7] Kaur, M. and Walia, P.K. 2016. Collection development of electronic resources in management libraries of India. Collection Building, 35(3), 73-83. https://doi.org/10.1108/C B-04-2016-0007

[8] Kissling, M.T. (2018). Social studies and beyond: attending to informal citizenship education in Schools. Social Studies Research and Practice, Vol. 13(2), 289-300. https://doi.org/10.1108/SSRP-06-2017-0033.

[9] Kumar, S. and Manjunath. G. 2013. Internet Use and its Impact on the Academic Performance of University Teachers and Researchers. A Comparative Study. Higher Education, Skills and Work Based Learning, 3(3), 219-238.

[10] Mushtaq, M. \& Tausif, A. (2020). Collection management of electronic resources in engineering college libraries of Aligarh, India: a study", Collection and Curation, 39(3), 89-96. https://doi.org/10.1108/CC-09-2019-0028.

[11] National Council for the Social Studies (NCSS). 2010. National curriculum standards for social studies: A framework for teaching, learning, and assessment. Washington, DC.

[12] National Council for the Social Studies. 2010. National curriculum standards for social studies: Introduction, MD. Silver Spring, Retrieved 15 July 2017 from http://www.socialstudies.org/standards/introduction.

[13] Ogungbeni, J. I., Adekanye, A.O., Bamigbose, A. A. and Sulaiman, M. A. 2016. Internet Use among Undergraduates in Nigeria: The Role of Policy. Journal of Information and Knowledge Management. 6(6). Pp 88-94. Retrieved 
November 18, 2017, from: http://www.iiste.org/Journals/ind ex.php/IKM/article/view/31039.

[14] Posigha, B.E., Oghuvwu, V., and Sunday, G. (2017). Awareness and Usage of Web Resources by Librarians in Nigeria. International Journal of Applied Technologies in Library and Information Management 3(1) 7, 57-65.

[15] Sadiat, A.S. (2014). An Evaluation of Undergraduates Use of E-Books: A Case of Federal University of Technology, Minna, Nigeria, International Research: Journal of Library \& Information Science, 4(4), 495-506.

[16] Ternenge, T.S. \& Kashimana, F. (2019). Availability, Accessibility, and Use of Electronic Information Resources for Research by Students in Francis Sulemanu Idachaba Library University of Agriculture, Makurdi. Library Philosophy and Practice (e-journal), 2352.
[17] Senthil, V. (2018). Does the more Internet usage provide good academic grades? Educ Inf Technol, 23, 2901-2910. https://doi.org/10.1007/s10639-018-9749-8.

[18] Tylor, J. (2015). An examination of how student journalists seek information and evaluate online sources during the newsgathering process. New Media \& Society, 17(8), 1277-1298. DOI: $10.1177 / 1461444814523079$.

[19] Beaudion, C.E. \& Tao, C.C. (2008). Modeling the impact of online cancer resources on supporters of cancer patients. New Media \& Society, 10(2), 321-344. DOI: $10.1177 / 1461444807086477$

[20]Dukić, D., \& Strišković, J. (2015). Croatian university students' use and perception of electronic resources. Library and Information Science Research, 37, 244-253. http://dx.doi.org/10.1016/j.lisr.2015.04.004. 